\title{
Zinc Speciation in Organic Waste Drives Its Fate in Amended Soils
}

\author{
Nounagnon Richard Hodomihou, Frédéric Feder, Samuel Legros, Thiago Augusto Formentini, \\ Enzo Lombi, and Emmanuel Doelsch*
}

Cite This: Environ. Sci. Technol. 2020, 54, 12034-12041

Read Online

ACCESS

Џlll Metrics \& More

Article Recommendations

Supporting Information

ABSTRACT: Recycling of organic waste (OW) as fertilizer on farmland is a widespread practice that fosters sustainable development via resource reuse. However, the advantages of OW fertilization should be weighed against the potentially negative environmental impacts due to the presence of contaminants such as zinc $(\mathrm{Zn})$. Current knowledge on the parameters controlling the environmental fate of $\mathrm{Zn}$ following $\mathrm{OW}$ application on cultivated soils is scant. We addressed this shortcoming by combining soil column experiments and $\mathrm{Zn}$ speciation characterization in OWs and amended soils. Soil column experiments were first carried out using two contrasted soils (sandy soil and sandy clay loam) that were amended with sewage sludge or poultry manure and cropped

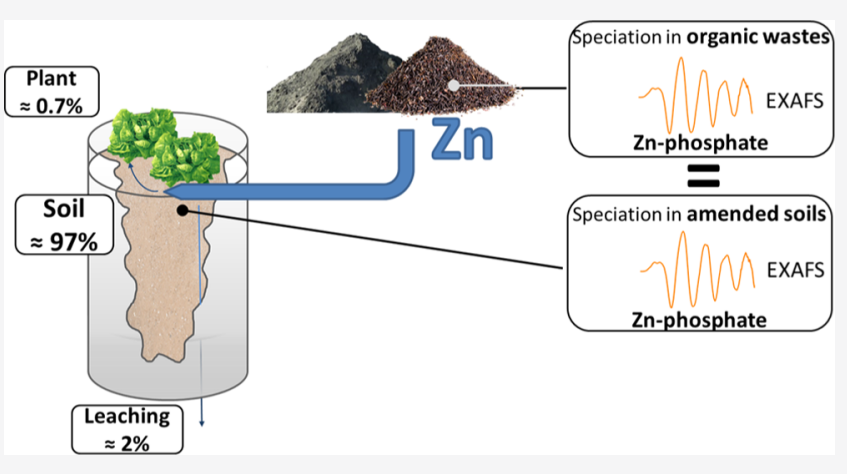
with lettuce. The soil columns were irrigated with identical amounts of water twice a week, and the leachates collected at the column outlet were monitored and analyzed. This scheme (OW application and lettuce crop cycle) was repeated for each treatment. Lettuce yields and $\mathrm{Zn}$ uptake were assessed at the end of each cycle. The soil columns were dismantled and seven soil layers were sampled and analyzed at the end of the second cycle (total experiment time: 12 weeks). X-ray absorption spectroscopy analyses were then conducted to assess $\mathrm{Zn}$ speciation in OW and OWamended soils. The results of this study highlighted that (i) the fate of $\mathrm{Zn}$ in water-soil-plant compartments was similar, regardless of the type of soil and OW, (ii) $>97.6 \%$ of the $\mathrm{Zn}$ input from OW accumulated in the soil surface layer, (iii) $\mathrm{Zn}$ uptake by lettuce increased with repeated OW applications, and (iv) no radical change in $\mathrm{Zn}$ speciation was observed at the end of the 12-week experiment, and phosphate was found to drive $\mathrm{Zn}$ speciation in both OW and amended soils (i.e., amorphous $\mathrm{Zn}$-phosphate and $\mathrm{Zn}$ sorbed on hydoxylapatite). These results suggest that $\mathrm{Zn}$ speciation in $\mathrm{OW}$ is a key determinant controlling the environmental fate of this element in OW-amended soils.

\section{INTRODUCTION}

The rapid increase in the African population (by 1.3 billion people between 2017 and $2050^{1}$ ) combined with the high urbanization rate $^{2}$ has led to an urban and periurban agriculture boom. ${ }^{3,4}$ In developing countries, market garden farming intensification is being achieved via inputs of biodegradable materials, such as sewage sludge (SS), livestock manure, green waste compost, and so forth, as soil fertilizers. These biodegradable materials, referred to as organic wastes (OWs), can supply a part or all of the nutrients needed for crops. ${ }^{4,5}$ However, many studies have highlighted negative impacts of agricultural OW recycling as fertilizers due to the presence of contaminants such as trace elements. ${ }^{6,7}$

A recent assessment of periurban Dakar (Senegal) agrosystems highlighted trace element contamination of OWamended cropped soils. ${ }^{8}$ Zinc (Zn) accumulation in soil surface layers has been explained by long-term repeated $\mathrm{Zn}$ rich OW application. ${ }^{8}$ Short-term vegetable crop cycles led to SS or poultry manure (PM) application up to nine times per year over a $24-40$ year period. The annual $\mathrm{Zn}$ input in periurban Dakar agrosystems ranged from 1369 to $5818 \mathrm{~g} \mathrm{ha}^{-1}$ year $^{-1}$, which is alarmingly higher than the 454-539 $\mathrm{g} \mathrm{ha}^{-1}$ year $^{-1}$ range in European countries and China. ${ }^{9-11}$ Surprisingly, $\mathrm{Zn}$ contamination was similar in the two main periurban Dakar agrosystems (Pikine and Rufisque) despite the fact that the properties of the soils in these two regions differ markedly. One is an arenosol (sandy soil, dune material) and the other a fluvisol (sandy clay loam and moderately calcareous soil). ${ }^{12}$ However, an analytical approach, ${ }^{8}$ involving a comparison of $\mathrm{Zn}$ contents in long-term cultivated plots versus adjacent uncultivated plots, did not enable (i) accurate monitoring of the $\mathrm{Zn}$ fate following OW spreading in the three water-soilplant system compartments and (ii) determination of the factors that could explain the similar fate of $\mathrm{Zn}$ in the contrasted soil types.

Received: April 29, 2020

Revised: July 14, 2020

Accepted: August 27, 2020

Published: August 27, 2020 
Table 1. Soil and OW Characteristics ${ }^{a}$

\begin{tabular}{|c|c|c|c|c|c|c|}
\hline & \multicolumn{2}{|r|}{ arenosol } & \multicolumn{2}{|c|}{ fluvisol } & \multirow[b]{2}{*}{ SS } & \multirow[b]{2}{*}{$\begin{array}{l}\text { poultry } \\
\text { manure }\end{array}$} \\
\hline & surface layer $(0-20 \mathrm{~cm})$ & deep layer $(20-40 \mathrm{~cm})$ & $\begin{array}{l}\text { surface layer } \\
(0-20 \mathrm{~cm})\end{array}$ & $\begin{array}{l}\text { deep layer } \\
(20-40 \mathrm{~cm})\end{array}$ & & \\
\hline clay $(\%)$ & 2.9 & 2.3 & 24.9 & 28.8 & & \\
\hline silt (\%) & 1.0 & 0.6 & 15.3 & 15.7 & & \\
\hline sand $(\%)$ & 96.2 & 97.1 & 59.9 & 55.5 & & \\
\hline $\begin{array}{l}\text { water-holding } \\
\text { capacity }(\%)\end{array}$ & 20.0 & 16.0 & 36.0 & 40.0 & & \\
\hline $\begin{array}{l}\text { total limestone } \\
\qquad\left(\mathrm{CaCO}_{3}\right)(\%)\end{array}$ & 6.0 & 2.5 & 24.8 & 23.9 & & \\
\hline pH (water) (-) & 7.7 & 7.2 & 8.6 & 8.8 & 6.2 & 8.3 \\
\hline $\mathrm{pH}(\mathrm{KCl})(-)$ & 7.6 & 7.0 & 7.3 & 7.7 & & \\
\hline organic carbon (\%) & 0.52 & 0.11 & 1.24 & 0.51 & 35.4 & 26.7 \\
\hline total nitrogen (\%) & 0.05 & 0.009 & 0.11 & 0.034 & 5 & 2.44 \\
\hline $\mathrm{C} / \mathrm{N}$ ratio $(-)$ & 10.6 & 12.2 & 11.7 & 15 & 7.1 & 10.9 \\
\hline ash $\left(\right.$ at $\left.500^{\circ} \mathrm{C}\right)(\%)$ & & & & & 34.0 & 49.0 \\
\hline total $\mathrm{P}\left(\mathrm{g} \mathrm{kg}^{-1}\right)$ & 0.23 & 0.20 & 0.66 & 0.24 & 16.8 & 17.3 \\
\hline $\begin{array}{l}\text { total } \mathrm{Zn}\left(\mathrm{mg} \mathrm{kg}^{-1}\right) \\
\text { mineralogy }\end{array}$ & $\begin{array}{l}23 \pm 2 \\
\text { quartz, cristobalite, sanidine, } \\
\text { muscovite }\end{array}$ & $\begin{array}{l}5.1 \pm 1.1 \\
\text { quartz, calcite, montmorillonite, } \\
\text { palygorskite, kaolinite }\end{array}$ & $28.8 \pm 1.3$ & $20.7 \pm 2.9$ & $1003 \pm 40$ & $320 \pm 30$ \\
\hline
\end{tabular}

X-ray absorption spectroscopy (XAS) is one of the most widely known structural techniques for direct determination of speciation of trace elements present in complex matrices, and it has been successfully applied to describe $\mathrm{Zn}$ speciation in different $\mathrm{OWs}^{13-18}$ or amended soils. ${ }^{19-22}$ Kirpichtchikova et al. $^{20}$ and Formentini et al. ${ }^{21}$ studied $\mathrm{Zn}$ speciation in soils affected by long-term application of sewage water and pig slurry, respectively. In both studies, $\mathrm{Zn}$ speciation in soils was dominated by its associations with secondary mineral phases (clay minerals and $\mathrm{Fe}$ oxyhydroxides). $\mathrm{Zn}$ speciation in OW was assessed by Formentini et al., ${ }^{21}$ revealing that nano-ZnS accounted for $100 \%$ of the speciation in the pig slurry. Yamamoto et al. ${ }^{22}$ recently investigated $\mathrm{Zn}$ speciation in pig manure compost and in a soil amended with this compost for 23 years. They showed that oxidized species present in the compost, that is, $\mathrm{Zn}$ phosphate and $\mathrm{Zn}$ bound to organic matter (OM), had persisted and accumulated in the amended soil. Although these studies agreed on the fact that $\mathrm{Zn}$ accumulated in the soil following OW spreading, their results were not consistent with respect to $\mathrm{Zn}$ speciation in OWs and in OW-amended soils.

The present study combined soil column experiments and $\mathrm{Zn}$ speciation analyses to characterize the fate of $\mathrm{Zn}$ in periurban Dakar agrosystems. Soil column experiments were first carried out using two contrasted soils that prevail in these agrosystems (i.e., an arenosol from Pikine and a fluvisol from Rufisque). SS or PM was applied at doses consistent with local agricultural practices, and the soil columns were cropped with lettuce (Lactuca sativa L.). Laboratory studies were conducted to thoroughly control water and solute fluxes and to obtain an accurate measurement of the mass balance of $\mathrm{Zn}$ distribution in the water-soil-plant system. XAS analyses were then used to assess $\mathrm{Zn}$ speciation in $\mathrm{OW}$ and $\mathrm{OW}$-amended soils from the soil column experiments. ${ }^{13-22}$

This combined approach enabled us to (i) monitor $\mathrm{Zn}$ fate in the three compartments of the water-soil-plant system and (ii) identify parameters controlling the fate of $\mathrm{Zn}$ following OW application on contrasted types of soil.

\section{MATERIALS AND METHODS}

OW and Soil Characteristics. Arenosol (Pikine; sandy soil, dune material) and fluvisol (Rufisque; sandy clay loam and moderately calcareous soil $)^{12}$ were selected for this study as they are the main soils in the periurban Dakar region, under the prevailing Sahelian tropical climatic conditions. The arenosol texture was dominated by the sand fraction (96.2$97.1 \%)$. Silt and clay accounted for $15.3-15.7$ and $24.9-28.8 \%$ of the fluvisol content, respectively (Tables 1, S1). The water holding capacity, total limestone, $\mathrm{pH}$, and organic carbon were much lower in the arenosol than in the fluvisol. Quartz, critobalite, sanidine, and muscovite mainly accounted for the mineralogy of the arenosol (Supporting Information S2). This contrasted with the fluvisol mineralogy, in which several clay minerals (kaolinite, montmorillonite, palygorskite, and kaolinite), calcite, and quartz were detected.

SS and PM are widely used as fertilizers in market gardens in periurban Dakar agrosystems. SS was sampled at the Pikine municipal wastewater treatment plant, and PM was sampled in a henhouse at Rufisque (Supporting Information S1). Both SS and PM had been stockpiled for long periods prior to being spread on the soil columns ( $>3$ months) which is consistent with market gardeners' practices. The ash content of SS (34\%) was lower than that for PM (49\%), whereas P concentrations were close for SS and PM (17.3 and $16.8 \mathrm{mg} \mathrm{kg}^{-1}$, respectively). The $\mathrm{Zn}$ concentration was higher in SS than in PM (1003 and $320 \mathrm{mg} \mathrm{kg}^{-1}$, respectively). The $\mathrm{Zn}$ concentration in SS was lower than the maximum permissible limits for land application in Europe $\left(2500-4000 \mathrm{mg} \mathrm{kg}^{-1}\right.$ DM) but higher than the most restrictive threshold values set by national legislation (Sweden: $800 \mathrm{mg} \mathrm{kg}^{-1}$; Netherlands: $\left.300 \mathrm{mg} \mathrm{kg}^{-1}\right) .^{23}$ The $\mathrm{Zn}$ concentration in PM was in very close agreement with $\mathrm{Zn}$ concentrations inventoried in the United States, Canada, and different European (Switzerland and Austria) and Asian (China and Japan) countries. ${ }^{24}$

Soil Column Experiment. The soil columns consisted of polyethylene cylinders $(50 \mathrm{~cm} \mathrm{~h}, 33 \mathrm{~cm}$ dia. $)$ that were reconstituted to reproduce in situ conditions. Two soil layers $(0-20$ and $20-40 \mathrm{~cm})$ were sampled in the arenosol and 
Table 2. Mass Balances in the Soil Column Experiments ${ }^{a}$

\begin{tabular}{|c|c|c|c|c|c|c|}
\hline & \multicolumn{3}{|c|}{ arenosol } & \multicolumn{3}{|c|}{ fluvisol } \\
\hline & control & SS-amended & PM-amended & control & SS-amended & PM-amended \\
\hline $\begin{array}{l}\text { (1) initial } \mathrm{Zn} \text { content in the soil } \\
\text { column }\end{array}$ & $809 \pm 67$ & $809 \pm 67$ & $809 \pm 67$ & $1168 \pm 98$ & $1168 \pm 98$ & $1168 \pm 98$ \\
\hline (2) $\mathrm{Zn}$ input from $O \mathrm{~W}^{b}$ & & $1029 \pm 41$ & $328 \pm 31$ & & $1029 \pm 41$ & $328 \pm 31$ \\
\hline $\begin{array}{l}\text { (3) Zn leaching at the soil } \\
\text { column outlet }^{c}\end{array}$ & $3.7 \pm 0.3$ & $\begin{array}{c}5.2 \pm 0.5 \\
(0.15 \% \pm 0.08 \%)\end{array}$ & $\begin{array}{c}9.9 \pm 0.9 \\
(1.9 \% \pm 0.56 \%)\end{array}$ & $12.6 \pm 2.2$ & $\begin{array}{c}9.3 \pm 3.5 \\
(0 \% \pm 0.50 \%)\end{array}$ & $\begin{array}{l}11.9 \pm 1.9 \\
(0 \% \pm 1.02 \%)\end{array}$ \\
\hline (4) Zn uptake by lettuce ${ }^{d}$ & $0.2 \pm 0.04$ & $\begin{array}{c}4.6 \pm 0.7 \\
(0.42 \% \pm 0.09 \%)\end{array}$ & $\begin{array}{c}1.8 \pm 0.2 \\
(0.46 \% \pm 0.12 \%)\end{array}$ & $0.7 \pm 0.1$ & $\begin{array}{c}4.4 \pm 0.7 \\
(0.36 \% \pm 0.10 \%)\end{array}$ & $\begin{array}{c}2.9 \pm 0.3 \\
(0.68 \% \pm 0.18 \%)\end{array}$ \\
\hline $\begin{array}{l}\text { (5) final } \mathrm{Zn} \text { content in the soil } \\
\text { column }\end{array}$ & $768 \pm 163$ & $1618 \pm 230$ & $912 \pm 130$ & $1366 \pm 133$ & $2267 \pm 132$ & $1567 \pm 91$ \\
\hline $\begin{array}{l}\text { (6) Zn balance: } \\
(1)+(2)-((3)+(4))\end{array}$ & $805 \pm 67^{\mathrm{NS} f}$ & $1828 \pm 110^{\mathrm{NS}}$ & $1126 \pm 99^{\mathrm{NS}}$ & $1154 \pm 100^{\mathrm{NS}}$ & $2183 \pm 143^{\mathrm{NS}}$ & $1481 \pm 131^{\mathrm{NS}}$ \\
\hline
\end{tabular}

${ }^{a}$ The $\mathrm{Zn}$ content is expressed in mg. ${ }^{b} \mathrm{Zn}$ input from $\mathrm{OW}=\mathrm{Zn}_{\mathrm{OWC} 1}+\mathrm{Zn}_{\mathrm{OWC} 2}$, where $\mathrm{Zn}_{\mathrm{OWC} 1}$ is the $\mathrm{Zn}$ input from SS or PM for cycle 1 , and $\mathrm{Zn}_{\mathrm{OWC} 2}$ is the $\mathrm{Zn}$ input from $\mathrm{SS}$ or PM for cycle $2 .{ }^{c} \mathrm{Zn}$ leaching at the soil column outlet $=\sum_{i=1}^{n}[\mathrm{Zn}]_{i} \times F_{i}$, where $[\mathrm{Zn}]_{i}$ is the $\mathrm{Zn}$ concentration measured in the leachate at week $i$, and $F_{i}$ is the water flux measured at the bottom of the column at week $i$. $n$ is the number of weeks $(n=12)$. Percentage of OW-derived $\mathrm{Zn}$ calculated after normalization by $\mathrm{Zn}$ leaching measured for the control soil column. ${ }^{d} \mathrm{Zn}$ uptake by lettuce $=\mathrm{Zn}$ PC1 + $\mathrm{Zn}_{\mathrm{PC} 2}$, where $\mathrm{Zn}_{\mathrm{PC} 1}$ is the mass $\mathrm{Zn}$ uptake by lettuce for cycle 1 , and $\mathrm{Zn}_{\mathrm{PC} 1}$ is the mass $\mathrm{Zn}$ uptake by lettuce for cycle 2. Percentage of OW-derived $\mathrm{Zn}$ calculated after normalization by $\mathrm{Zn}$ uptake measured for the control soil column. ${ }^{e}$ Final $\mathrm{Zn}$ content in the soil column $=\sum_{j=1}^{m}[\mathrm{Zn}]_{j} \times \mathrm{MSl}_{j}$, where $[\mathrm{Zn}]_{j}$ is the $\mathrm{Zn}$ concentration measured in soil layer $j$, and $\mathrm{MSl}_{j}$ is the mass of soil layer $j . m$ is the number of soil layers $(m=7) .{ }^{f} \mathrm{NS}=$ no significant difference between the final $\mathrm{Zn}$ content in the soil column (5) and the $\mathrm{Zn}$ balance (6) at the 5\% level.

fluvisol. Soils were air-dried, crumbled, and then reconstituted while maintaining the soil bulk densities measured in situ ( 1.65 $\mathrm{kg} \mathrm{dm}^{-3}$ for the arenosol and $1.4 \mathrm{~kg} \mathrm{dm}^{-3}$ for the fluvisol). The weight of arenosol was $56 \mathrm{~kg}$ column ${ }^{-1}\left(47 \mathrm{~kg}\right.$ column $^{-1}$ for fluvisol). SS and PM were applied at the surface of the soil columns at $60 \mathrm{~T} \mathrm{ha}^{-1}\left(0.51 \mathrm{~kg}\right.$ column $\left.{ }^{-1}\right)$. Control soil columns without $\mathrm{OW}$ application $\left(0 \mathrm{~T} \mathrm{ha}^{-1}\right)$ were also monitored. Three replicates per treatment (a treatment is defined as a type of soil amended with a type of OW) were performed, representing a total of 18 soil columns.

Lettuce (L. sativa L.) was cultivated 1 week after the OW application. During the crop cycle (5 weeks), soil columns received $4 \mathrm{~L}$ of water twice a week, corresponding to $46.8 \mathrm{~mm}$ or 0.3 pore volume (PV) for the arenosol and $0.25 \mathrm{PV}$ for the fluvisol. Leached soil solutions were sampled at the bottom of the soil columns weekly and analyzed for $\mathrm{pH}, \mathrm{Zn}$ concentration, and dissolved organic carbon (DOC). Lettuce leaves were harvested at the end of the crop cycle. Dry biomass was weighed to determine yields and $\mathrm{Zn}$ uptake.

This scheme (OW application and lettuce crop cycle) was repeated for each treatment. At the end of the second cycle (total experiment time: 12 weeks), the soil columns were dismantled and seven soil layers were sampled and analyzed.

The experimental procedure is described in further detail in the Supporting Information S3.

Zinc Speciation in OWs and Soils. XAS was applied to assess the speciation of $\mathrm{Zn}$ in $\mathrm{OW}$ and the surface layer (0-3 $\mathrm{cm}$ ) of amended soils (SS-amended fluvisol, PM-amended fluvisol, and SS-amended arenosol). Zn K-edge XAS spectra were recorded at the ESRF synchrotron (Grenoble, France) on the BM30B (FAME) beamline. Dried OW and soil samples were cryo-ground (Retsch MM400) and pressed into pellets before analysis. Spectra were measured at liquid helium temperature, to minimize beam-induced damage of the samples, in the fluorescence mode with a 30-element solidstate Ge detector. The spectra of each sample were an average of three to seven scans, depending on the $\mathrm{Zn}$ concentration and the signal-to-noise ratio. The acquisition of extended X-ray absorption fine structure (EXAFS) spectra for the PMamended arenosol was not possible due to the combination of a low $\mathrm{Zn}$ concentration and a very high $\mathrm{Fe}$ concentration.
Each scan was measured on a different spot on the sample pellet to limit beam damage. Energy calibration was performed using a metallic $\mathrm{Zn}$ reference foil recorded simultaneously with the samples. The absorption edge was defined at $9659 \mathrm{eV}$, as indicated by the zero crossing of the second derivative of the Zn-foil spectrum. A similar procedure was applied to the previously acquired spectra of $\mathrm{Zn}$ reference compounds. Normalization and data reduction were performed according to standard methods ${ }^{25}$ using Athena software. ${ }^{26}$ A library of spectra from $\mathrm{Zn}$ reference compounds was used to identify $\mathrm{Zn}$ species in OW and the soil (Supporting Information S4). These references have been synthesized or purchased and described in previously published studies: nano- $\mathrm{ZnS}$ and amorphous $\mathrm{Zn}$-phosphate; ${ }^{13} \mathrm{Zn}$ sorbed on goethite and $\mathrm{Zn}$ sorbed on ferrihydrite; ${ }^{27} \mathrm{Zn}$ cryptomelane; ${ }^{28} \mathrm{Zn}$-layered double hydroxide, $\mathrm{Zn}$ sorbed on hydroxy-Al interlayered montmorillonite; ${ }^{29} \mathrm{Zn}$ sorbed on kaolinite; ${ }^{30} \mathrm{Zn}$ sorbed on hydroxylapatite; ${ }^{31}$ Zn-malate, Zn-histidine, Zn-cysteine; ${ }^{27,32}$ Zn-methionine; ${ }^{15,33}$ Zn-phytate; ${ }^{15,34}$ and Zn-oxalate, crystalline $\mathrm{Zn}$ phosphate, and sphalerite (reagent grade, SigmaAldrich). Reference material spectra and sample spectra were measured in the same conditions. Least square linear combination fitting (LCF, Supporting Information S5) was performed for each OW or amended soil spectrum over a $k$ range of 2.5-10.6 $\mathrm{c5}^{-1}$. The residual factor of each LCF was calculated as follows: $R=\Sigma\left(k^{3} \chi(k)_{\exp }-k^{3} \chi(k)_{\mathrm{fit}}\right)^{2} / \Sigma\left(k^{3} \chi\right.$ $\left.(k)_{\text {exp }}\right)^{2}$. At each step of the fitting, an additional reference spectrum was added and retained in the result if the following two conditions were true: (i) the residual factor decreased by $20 \%$ or more and (ii) the additional reference had a contribution equal to or higher than $10 \%$ among $\mathrm{Zn}$-species used for the fit. The uncertainty of this LCF method was estimated at $\pm 15 \%$. $^{25}$

Statistical Analysis. Data are presented as means of three independent soil columns and mean values were taken for statistical analyses using one-way ANOVA. Significant differences were further analyzed using the Student-NewmanKeuls test to identify differences between modalities. The differences were considered significant if $p \leq 0.05$. 

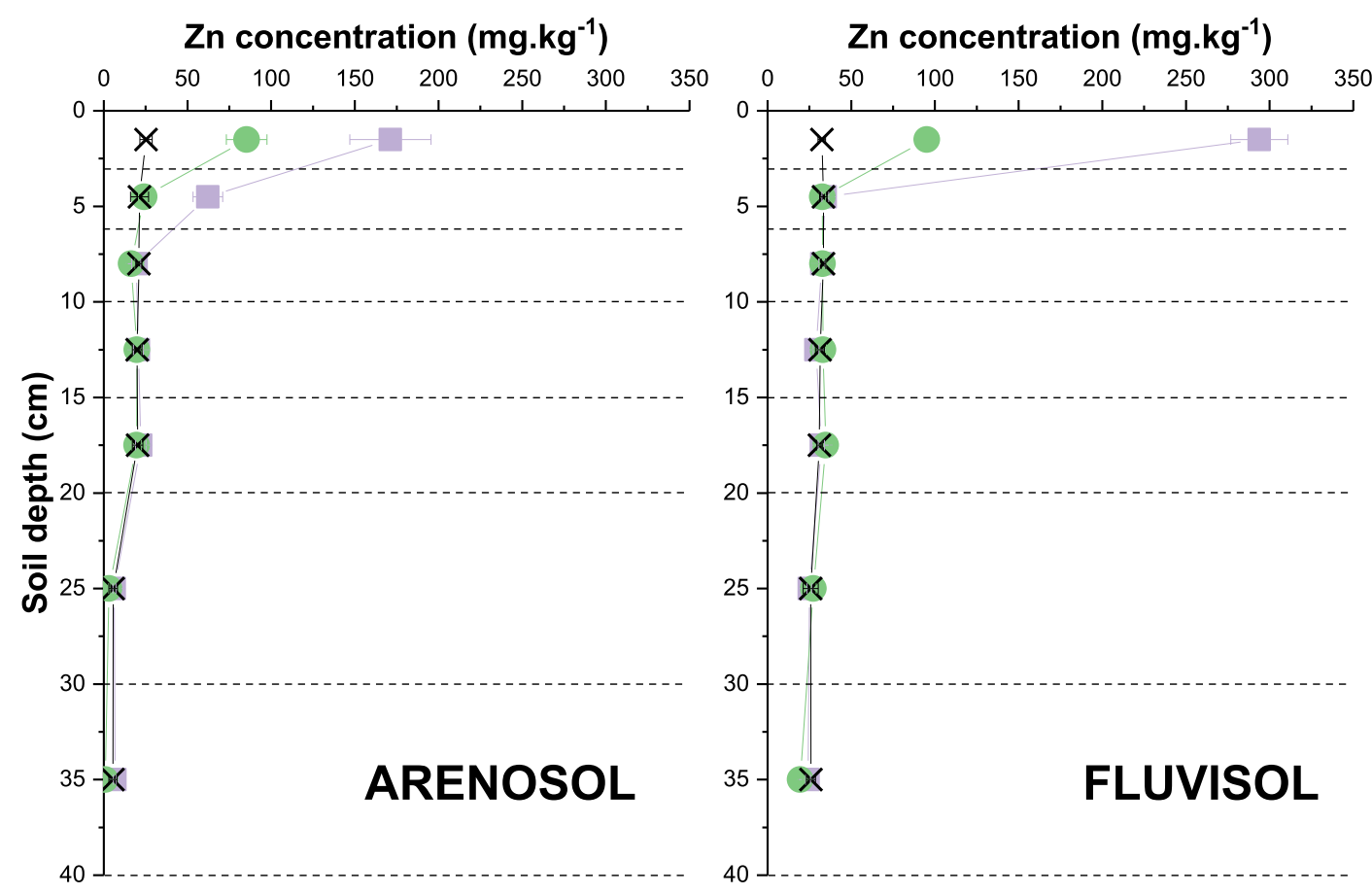

\section{Sewage sludge-amended}

\section{Poultry manure-amended $-\mathrm{X}-$ Control}

Figure 1 . $\mathrm{Zn}$ concentration $\left(\mathrm{mg} \mathrm{kg}^{-1}\right)$ in the arenosol and fluvisol soil layers at the end of the soil column experiment. Dashed lines represent the analyzed soil layers.

\section{RESULTS AND DISCUSSION}

Accumulation of OW-Borne $\mathrm{Zn}$ in the Soil Surface Layer. The different mass balance terms in the soil column experiments are shown in Table 2. Note that the $\mathrm{Zn}$ mass balance [(initial $\mathrm{Zn}$ content in the soil column $+\mathrm{Zn}$ input from OW $)-(\mathrm{Zn}$ leaching at the soil column outlet $+\mathrm{Zn}$ uptake by lettuce)] was not statistically different from the final $\mathrm{Zn}$ content in the soil column, indicating that the different mass balance terms had been accurately quantified and no compartments (soil, plant, or leaching) were overlooked. Since $\mathrm{Zn}$ concentrations in the OWs varied (see Table 1), Zn inputs in the amended soils were different: SS application provided 3.1-fold more $\mathrm{Zn}$ than PM (1029 and $328 \mathrm{mg}$, respectively, for the whole experiment).

For the fluvisol columns, there was no significant difference between the leached $\mathrm{Zn}$ concentration at the outlet when comparing the control and the amended columns, indicating that exogenous $\mathrm{Zn}$ (i.e., $\mathrm{Zn}$ derived from $\mathrm{OW}$ ) was not leached from the fluvisol column. In contrast, arenosol promoted leaching of a minor fraction of the exogenous $\mathrm{Zn}$. The leached $\mathrm{Zn}$ at the outlet of the arenosol columns represented $0.15 \%$ of the $\mathrm{Zn}$ input in the SS-amended soil and $1.9 \%$ of the $\mathrm{Zn}$ input in the PM-amended soil.

For both soils, OW application enhanced $\mathrm{Zn}$ uptake by lettuce as compared to the control soil. Total $\mathrm{Zn}$ uptake by lettuce (cumulated for the two cycles) was similar regardless of the treatment (soil + OW), ranging from $0.36 \%$ (SS-amended fluvisol) to $0.68 \%$ (PM-amended fluvisol) of the $\mathrm{Zn}$ inputs.

Soil column dismantling and analysis at the end of the two crop cycles highlighted the accumulated $\mathrm{Zn}$ distribution through the soil profile (Figure 1). In the fluvisol, exogenous $\mathrm{Zn}$ remained entirely in the $0-3 \mathrm{~cm}$ surface layer for both SSand PM-amended soils. In the arenosol, exogenous $\mathrm{Zn}$ was distributed in the $0-3$ and 3-6 cm layers for the SS-amended soil and $0-3 \mathrm{~cm}$ for the $\mathrm{PM}$-amended soil. $\mathrm{Zn}$ derived from OWs was therefore not transferred through the soil profile to deeper layers.

Overall, 99.6, 99.3, and 99.4\% of OW-borne $\mathrm{Zn}$ accumulated in the upper soil layers $(0-3$ and 3-6 cm) for the SS-amended fluvisol, PM-amended fluvisol, and SS-amended arenosol, respectively, whereas $97.6 \%$ of $\mathrm{Zn}$ accumulated in the $0-3$ $\mathrm{cm}$ soil layer for the PM-amended arenosol. This exogenous $\mathrm{Zn}$ accumulation in the upper soil layers after OW spreading has already been observed. For instance, Formentini et al. assessed the impact of 11 years of pig slurry spreading in a clayey Hapludox soil. They concluded that most exogenous $\mathrm{Zn}$ accumulated within the topsoil layers, with assimilation by crops and leaching virtually negligible in the overall $\mathrm{Zn}$ balance.

This study specifically highlighted a soil effect. The arenosol promoted leaching of a small fraction of $\mathrm{Zn}$ in drained water (Supporting Information S6) and migration from 0 to $6 \mathrm{~cm}$ depth (Figure 1). The sandy texture of the arenosol associated with its high hydraulic conductivity might have favored particulate or dissolved $\mathrm{Zn}$ movement. Conversely, higher clay, carbonate, and $\mathrm{OM}$ contents, basic $\mathrm{pH}$, and the higher cation exchange capacity of the fluvisol might have favored $\mathrm{Zn}$ accumulation in the surface layer (Figure 1).

An OW effect was also highlighted. We observed a $1 \mathrm{pH}$ unit time-course decrease in the solution collected at the outlet of the SS-amended arenosol (Supporting Information S6). This decrease in $\mathrm{pH}$ is common and attributed to the acidic effect of OW mineralization and the ammonium nitrification process. $^{27,35,36}$ It is well established that $\mathrm{pH}$ is the major driver of $\mathrm{Zn}$ solubility in soils ${ }^{37}$ and the observed decrease in $\mathrm{pH}$ favored $\mathrm{Zn}$ leaching in the SS-amended arenosol. However, $\mathrm{Zn}$ 
a

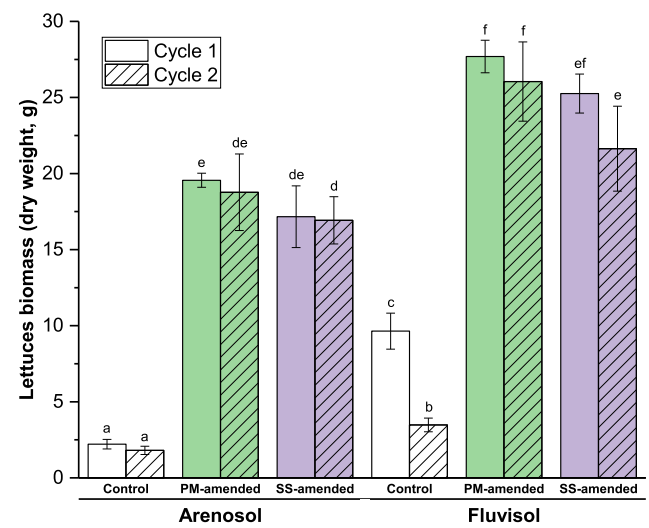

b

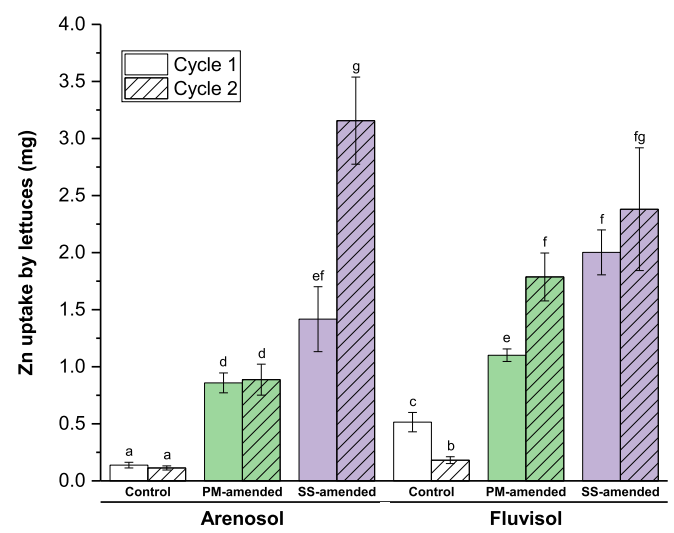

Figure 2. (a) Mean harvested lettuce dry biomass per soil column (g) and (b) mean Zn uptake by lettuces per soil column (mg). Different letters represent significant differences between treatments at the 5\% level. PM: poultry manure; SS: sewage sludge.

leaching at the outlet of the PM-amended arenosol column (1.9\% of the $\mathrm{Zn}$ input) was surprising as the $\mathrm{pH}$ of the soil solution was stable and slightly alkaline $(\mathrm{pH}=7.3-8)$ throughout the experiment (Supporting Information S6). Nevertheless, Zn leaching was closely correlated with the DOC at the column outlet (Supporting Information S7). Complexation with organic ligands could have mobilized a fraction of exogenous $\mathrm{Zn}$. Several studies concluded that colloidal transport can favor trace element transfer in soils following OW spreading. For example, Karathanasis et al. ${ }^{38}$ studied $\mathrm{Cu}, \mathrm{Zn}$, and $\mathrm{Pb}$ elution in a soil monolith. They demonstrated the elution of significant soluble metal loads in association with water-dispersible biosolid colloids. Similarly, Yamamoto et al. ${ }^{22}$ studied the fate of $\mathrm{P}, \mathrm{Zn}$, and $\mathrm{Cu}$ in soil affected by a long-term application of swine manure compost. They demonstrated that continual compost application enhanced the formation of a soil water-dispersible colloid in which $\mathrm{Zn}, \mathrm{Cu}$, and $\mathrm{P}$ were accumulated.

Zinc Uptake by Lettuce Increases with Repeated OWs Application. For both soils, PM or SS application significantly increased the lettuce biomass in comparison to the unfertilized control soil (Figure 2a). No significant differences in yields were found between the first and second lettuce crop cycles within the same treatment (except for the fluvisol control, for which a decrease in dry biomass was observed). This highlights the fertilization value of OW, which represents a potential alternative to inorganic fertilizers for crop production. ${ }^{39}$

Significantly higher $\mathrm{Zn}$ uptake by lettuce was measured in the OW-amended soils than in the control soils (Figure $2 b$ ). Moreover, we observed a significant increase in $\mathrm{Zn}$ uptake by lettuce between the first and second OW application for the SS-amended arenosol and PM-amended fluvisol. This was also observed for the other two treatments (PM-amended arenosol and SS-amended fluvisol), but these findings were not statistically significant.

If this trend, that is, constant crop yield combined with increased $\mathrm{Zn}$ uptake, were to be confirmed by long-term experiments with repeated OW application and successive crop cycles, OW fertilization could represent an opportunity to improve the $\mathrm{Zn}$ content of staple food crops. Such agronomic biofortification ${ }^{40}$ could help tackle $\mathrm{Zn}$ deficiency in human populations which is a cause of illness and death in developing countries. ${ }^{41}$ The advantages of using OW to increase the plant
Zn concentration should, however, be assessed together with the potential uptake of toxic trace elements such as $\mathrm{Cd}$ or $\mathrm{Pb}$.

Phosphate Drives Zn Speciation in OWs and Amended Soils. The quantitative LCF results (expressed as a percentage of each $\mathrm{Zn}$ species) obtained for both $\mathrm{OW}$ and OW-amended soils $(0-3 \mathrm{~cm}$ soil layer) collected at the end of the experiment are shown in Figure 3. The experimental data

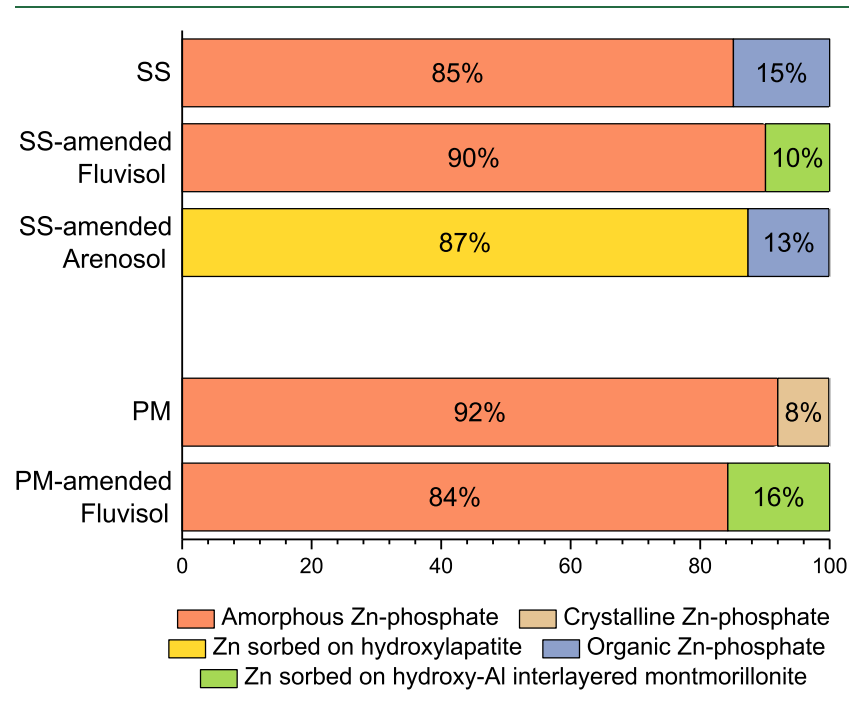

Figure 3. $\mathrm{Zn}$ speciation determined from the linear combination fitting of the $\mathrm{Zn}$ K-edge EXAFS spectroscopy data ( $\mathrm{PM}=$ poultry manure, $\mathrm{SS}=$ sewage sludge).

were modeled with two $\mathrm{Zn}$ references per sample and total contributions ranged from 89 to $111 \%$ (Supporting Information S5, SI8). Zn species contributions were normalized to $100 \%$ for easier comparison. The $R$-factor of the LCFs ranged from 0.029 to 0.063 .

Zn Speciation in OWs. Zinc phosphate (organic, amorphous, or crystalline) accounted for $100 \%$ of $\mathrm{Zn}$ speciation in SS and PM, which is in agreement with the high affinity of $\mathrm{Zn}$ for phosphate compounds. ${ }^{42}$ Amorphous $\mathrm{Zn}$ phosphate was found to be the main $\mathrm{Zn}$ species in SS (85\%) and PM (92\%). The second $\mathrm{Zn}$ species was another form of $\mathrm{Zn}$ phosphate: organic $\mathrm{Zn}$ phosphate (15\% in SS) or crystalline $\mathrm{Zn}$ phosphate ( $8 \%$ in $\mathrm{PM})$. Hopeite (crystalline $\mathrm{Zn}$ phosphate) has already been documented in previous studies as a major $\mathrm{Zn}$ phase in OWs. ${ }^{15,16,18,22,43}$ 
In the present study, the amorphous $\mathrm{Zn}$ phosphate reference closely matched the $\mathrm{Zn}$ speciation of PM and SS. These findings are in accordance with those of a recent survey of $\mathrm{Zn}$ speciation in a large series of OW sampled in full-scale plants ${ }^{13}$ where it was reported for the first time that the main $\mathrm{Zn}$ species in compost or stockpiled OW was amorphous $\mathrm{Zn}$ phosphate $(40-100 \%)$. In this survey, Le Bars et al. ${ }^{13}$ also demonstrated that nanosized $\mathrm{Zn}$ sulfide (nano- $\mathrm{ZnS}$, with a crystallite size of $3 \pm 0.4 \mathrm{~nm}$ ) was a major $\mathrm{Zn}$ species in liquid agricultural OW and SS. This contrasts with our result as zinc phosphate accounted for $100 \%$ of $\mathrm{Zn}$ speciation in the studied SS. Nevertheless, these discrepancies could be explained by the chemical instability of nano- $\mathrm{ZnS}$ which becomes a minor species after OW composting or stockpiling. ${ }^{13,16}$ As the SS and PM in the present study had been stockpiled for a long period (>3 months), they were exposed to atmospheric conditions, which favors nano- $\mathrm{ZnS}$ oxidative dissolution and could explain why nano- $\mathrm{ZnS}$ were no longer observed and were replaced by Zn phosphate species.

Zn Speciation in Amended Soils. The best LCFs for both SS-amended and PM-amended fluvisol were achieved by combining the same references at almost the same proportions. Amorphous $\mathrm{Zn}$ phosphate was the main species, that is, $84 \%$ for PM-amended fluvisol and $90 \%$ for SS-amended fluvisol. $\mathrm{Zn}$ sorbed on hydroxy-Al interlayered montmorillonite (HIM) was the secondary $\mathrm{Zn}$ species, that is, $16 \%$ for PM-amended fluvisol and $10 \%$ for SS-amended fluvisol. The latter mineral reference was supported by the X-ray diffraction clay mineral findings in the fluvisol (Supporting Information S2). For SSamended fluvisol, the $\mathrm{Zn}$ speciation pattern was in very close agreement with the $\mathrm{Zn}$ distribution in the $0-3 \mathrm{~cm}$ soil layer: the proportion of exogenous $\mathrm{Zn}$ derived from SS represented $90 \%$ of the total soil $\mathrm{Zn}$ concentration, while the proportion inherited from the pedo-geochemical background represented $10 \%$ (Figure 1). This agreement was less satisfactory for PMamended fluvisol: $\mathrm{Zn}$ speciation was characterized as $84 \%$ amorphous $\mathrm{Zn}$ phosphate $+16 \% \mathrm{Zn}$ sorbed on HIM, whereas the proportion of exogenous $\mathrm{Zn}$ derived from PM represented $66 \%$ of $\mathrm{Zn}$ concentration in the total soil, while the proportion of endogenous $\mathrm{Zn}$ represented 34\% (Figure 1). In this case, the poor quality of the EXAFS spectra (Supporting Information S5), as well as the uncertainty of the LCF method $( \pm 15 \%)$, could explain this discrepancy. The SS-amended arenosol contained $87 \%$ of $\mathrm{Zn}$ sorbed on hydoxylapatite and $13 \%$ of $\mathrm{Zn}$ phytate, an organic $\mathrm{Zn}$ phosphate already detected in the SS. Zn sorbed on hydroxylapatite was not detected in SS, in which amorphous $\mathrm{Zn}$ phosphate was found to be the main $\mathrm{Zn}$ species. However, the featureless shape of the $\mathrm{Zn}$ sorbed on the hydoxylapatite EXAFS spectrum suggested that this phase was a $\mathrm{Zn}$-sorption surface complex or a poorly crystalline $\mathrm{Zn}$ phosphate precipitate. ${ }^{31}$ This change of speciation (amorphous $\mathrm{Zn}$ phosphate to $\mathrm{Zn}$ sorbed on hydoxylapatite) was not fully understood but could be explained by the acidification of the soil solution ( $-1 \mathrm{pH}$ unit, Supporting Information S6) due to OM mineralization. In brief, no radical change in $\mathrm{Zn}$ speciation was observed at the end of the 12-week experiment (two OW applications and two lettuce crop cycles) and phosphate was the main driver of $\mathrm{Zn}$ speciation in both OWs and amended soils.

Previous Studies and New Findings: the Benefits of Assessing the Source Speciation to Predict the Environmental Fate. To our knowledge, no previous studies have assessed the fate of OW-borne amorphous $\mathrm{Zn}$ phosphate species in the soil after OW spreading. More importantly, our results differed substantially from those of previous studies using XAS techniques. ${ }^{19-22}$ Mamindy-Pajany et al. ${ }^{19}$ described $\mathrm{Zn}$ speciation in a soil mixed with SS and spiked with a $\mathrm{Zn}$ nitrate solution. Their results $(58 \% \mathrm{Zn}$ sorbed to $\mathrm{Fe}$ oxyhydroxides and $42 \% \mathrm{Zn}$ bound to $\mathrm{OM}$ ) highlighted the soil retention mechanism with respect to $\mathrm{Zn}$ rather than the fate of exogenous $\mathrm{OW}$-derived $\mathrm{Zn}$. In two studies by Kirpichtchikova et al. ${ }^{20}$ and Formentini et al., ${ }^{21} \mathrm{Zn}$ speciation in soils affected by long-term sewage water and pig slurry application was dominated by its associations with secondary mineral phases (clay minerals and $\mathrm{Fe}$ oxyhydroxides). Surprisingly, nano-ZnS accounted for $100 \%$ of the $\mathrm{Zn}$ speciation in the pig slurry, ${ }^{21}$ but nano-ZnS was not detected in the amended soil. The authors assumed that the nano-scale of $\mathrm{ZnS}$ favored oxidation of this species in the soil, in turn releasing $\mathrm{Zn}$ that was subsequently retained by the soil matrix. We think that an identical mechanism could explain the $\mathrm{Zn}$ speciation in the soil amended by sewage water, ${ }^{20}$ since the conditions in liquid OW are often reducing, hence leading to the formation of nano- $\mathrm{ZnS},{ }^{13}$ which might have oxidized and dissolved after sewage water spreading.

Yamamoto et al. ${ }^{22}$ investigated $\mathrm{Zn}$ speciation in pig manure compost and in a soil amended with this compost for 23 years. Their results highlighted that oxidized species present in the compost, that is, Zn-phosphate and $\mathrm{Zn}$ bound to OM, had persisted and accumulated in the amended soil. Our results confirmed that $\mathrm{Zn}$ present in OW stockpiled for a long period (>3 months) did not undergo a considerable change in speciation after OW application and was mainly accumulated in the soil surface horizon, despite the highly contrasting properties of both studied soils.

After the application of fresh OW with a high $\mathrm{Zn}$ sulfide content, the final $\mathrm{Zn}$ speciation would be soil dependent as the sulfide would oxidize and release $\mathrm{Zn}$, which in turn would be sorbed/precipitated on the soil matrix. ${ }^{13,21}$ Conversely, if the OW had been stockpiled/composted with sufficient phosphate present, then OW-borne $\mathrm{Zn}$ phosphate species accumulate and persist in the amended soil.

The results of the present study and the aforementioned studies jointly point toward the same conclusion. Speciation of trace elements in the source, that is, OW, is the main driver that controls the $\mathrm{Zn}$ fate in the soil-plant-water compartments following OW application. Neglecting trace element speciation in the contamination source ( $\mathrm{OW}$ in this case) hampers gaining further insight into the environmental fate of contaminants in amended soils.

\section{ASSOCIATED CONTENT}

\section{Supporting Information}

The Supporting Information is available free of charge at https://pubs.acs.org/doi/10.1021/acs.est.0c02721.

Soil, plant, leached water, and OW sampling procedure, analytical methods, and experimental design; X-ray diffraction; $\mathrm{Zn}$ K-edge EXAFS spectra and radial distribution function of reference compounds; LCF results; variations in $\mathrm{pH}, \mathrm{DOC}$, and $\mathrm{Zn}$ in the drained water at the soil column outlets; and comparison of EXAFS spectra and radial distribution function of reference compounds (PDF) 


\section{AUTHOR INFORMATION}

\section{Corresponding Author}

Emmanuel Doelsch - UPR Recyclage et Risque, CIRAD, F34398 Montpellier, France; Recyclage et Risque, Univ. Montpellier, CIRAD, Montpellier, France; O orcid.org/00000002-7478-4296; Email: doelsch@cirad.fr

\section{Authors}

Nounagnon Richard Hodomihou - UPR Recyclage et Risque, CIRAD, 18524 Dakar, Senegal; Recyclage et Risque, Univ. Montpellier, CIRAD, Montpellier, France

Frédéric Feder - UPR Recyclage et Risque, CIRAD, 18524 Dakar, Senegal; Recyclage et Risque, Univ. Montpellier, CIRAD, Montpellier, France

Samuel Legros - UPR Recyclage et Risque, CIRAD, 18524 Dakar, Senegal; Recyclage et Risque, Univ. Montpellier, CIRAD, Montpellier, France; (1) orcid.org/0000-0001-7081-6679

Thiago Augusto Formentini - Laboratory of Environmental Engineering, Federal University of Santa Maria (UFSM), 97105-900 Santa Maria, Rio Grande do Sul, Brazil; Department of Soil and Environment, Swedish University of Agricultural Sciences, SE-75007 Uppsala, Sweden

Enzo Lombi - Future Industries Institute, University of South Australia, Adelaide, South Australia 5095, Australia; (1) orcid.org/0000-0003-3384-0375

Complete contact information is available at: https://pubs.acs.org/10.1021/acs.est.0c02721

\section{Notes}

The authors declare no competing financial interest.

\section{ACKNOWLEDGMENTS}

This study was part of the "Negative externalities of land cultivation intensification in periurban areas" project funded by West and Central African Council for Agricultural Research and Development (CORAF/WECARD). The authors wish to thank LMI IESOL for hosting and IMAGO (IRD, Dakar) for laboratory analysis. The authors are grateful to the French Agricultural Research Centre for International Development (CIRAD) for funding the $\mathrm{PhD}$ scholarship of Richard Hodomihou. We are grateful to the European Synchrotron Radiation Facility (ESRF) for providing access to the synchrotron radiation facilities. E.D. has received funding from the EU Horizon 2020 Framework Programme for Research and Innovation under the Marie Skodowska-Curie actions agreement no. 795614 .

\section{REFERENCES}

(1) United Nations Department of Economic and Social Affairs. Population Division, World Population Prospects: The 2017 Revision, 2017; Vol. Volume I: comprehensive tables (ST/ESA/SER.A/399), p 346.

(2) United Nations Department of Economic and Social Affairs. Population Division, World Urbanization Prospects: The 2014 Revision, 2014; Vol. Highlights (ST/ESA/SER.A/352), p 27.

(3) Orsini, F.; Kahane, R.; Nono-Womdim, R.; Gianquinto, G. Urban agriculture in the developing world: a review. Agron. Sustainable Dev. 2013, 33, 695-720.

(4) Bon, H.; Parrot, L.; Moustier, P. Sustainable urban agriculture in developing countries. A review. Agron. Sustainable Dev. 2010, 30, 2132.

(5) Diallo, F.; Masse, D.; Diarra, K.; Feder, F. Impact of organic fertilisation on lettuce biomass production according to the cultivation duration in tropical soils. Acta Agric. Scand., Sect. B 2020, 70, 215-223.

(6) Formentini, T. A.; Mallmann, F. J. K.; Pinheiro, A.; Fernandes, C. V. S.; Bender, M. A.; da Veiga, M.; dos Santos, D. R.; Doelsch, E. Copper and zinc accumulation and fractionation in a clayey Hapludox soil subjectto long-term pig slurry application. Sci. Total Environ. 2015, 536, 831-839.

(7) Legros, S.; Doelsch, E.; Feder, F.; Moussard, G.; Sansoulet, J.; Gaudet, J.-P.; Rigaud, S.; Doelsch, I. B.; Macary, H. S.; Bottero, J.-Y. Fate and behaviour of $\mathrm{Cu}$ and $\mathrm{Zn}$ from pig slurry spreading in a tropical water-soil-plant system. Agric., Ecosyst. Environ. 2013, 164, $70-79$.

(8) Hodomihou, N. R.; Feder, F.; Masse, D.; Agbossou, K. E.; Amadji, G. L.; Ndour-Badiane, Y.; Doelsch, E. Diagnosis of periurban Dakar (Senegal) agrosystem contamination by trace elements. Biotechnol., Agron., Soc. Environ. 2016, 20, 397-407.

(9) Belon, E.; Boisson, M.; Deportes, I. Z.; Eglin, T. K.; Feix, I.; Bispo, A. O.; Galsomies, L.; Leblond, S.; Guellier, C. R. An inventory of trace elements inputs to French agricultural soils. Sci. Total Environ. 2012, 439, 87-95.

(10) Nicholson, F. A.; Smith, S. R.; Alloway, B. J.; Carlton-Smith, C.; Chambers, B. J. An inventory of heavy metals inputs to agricultural soils in England and Wales. Sci. Total Environ. 2003, 311, 205-219.

(11) Luo, L.; Ma, Y.; Zhang, S.; Wei, D.; Zhu, Y.-G. An inventory of trace element inputs to agricultural soils in China. J. Environ. Manage. 2009, 90, 2524-2530.

(12) Working Group WRB, I. World Reference Base for Soil Resources 2014. International Soil Classification System for Naming Soils and Creating Legends for Soil Maps, 2014.

(13) Le Bars, M.; Legros, S.; Levard, C.; Chaurand, P.; Tella, M.; Rovezzi, M.; Browne, P.; Rose, J.; Doelsch, E. Drastic Change in Zinc Speciation during Anaerobic Digestion and Composting: Instability of Nanosized Zinc Sulfide. Environ. Sci. Technol. 2018, 52, 1298712996.

(14) Legros, S.; Doelsch, E.; Masion, A.; Rose, J.; Borschneck, D.; Proux, O.; Hazemann, J.-L.; Saint-Macary, H.; Bottero, J.-Y. Combining Size Fractionation, Scanning Electron Microscopy, and X-ray Absorption Spectroscopy to Probe Zinc Speciation in Pig Slurry. J. Environ. Qual. 2010, 39, 531-540.

(15) Legros, S.; Levard, C.; Marcato-Romain, C.-E.; Guiresse, M.; Doelsch, E. Anaerobic Digestion Alters Copper and Zinc Speciation. Environ. Sci. Technol. 2017, 51, 10326-10334.

(16) Donner, E.; Howard, D. L.; Jonge, M. D. d.; Paterson, D.; Cheah, M. H.; Naidu, R.; Lombi, E. X-ray Absorption and Micro Xray Fluorescence Spectroscopy Investigation of Copper and Zinc Speciation in Biosolids. Environ. Sci. Technol. 2011, 45, 7249-7257.

(17) Donner, E.; Ryan, C. G.; Howard, D. L.; Zarcinas, B.; Scheckel, K. G.; McGrath, S. P.; de Jonge, M. D.; Paterson, D.; Naidu, R.; Lombi, E. A multi-technique investigation of copper and zinc distribution, speciation and potential bioavailability in biosolids. Environ. Pollut. 2012, 166, 57-64.

(18) Lombi, E.; Donner, E.; Tavakkoli, E.; Turney, T. W.; Naidu, R.; Miller, B. W.; Scheckel, K. G. Fate of Zinc Oxide Nanoparticles during Anaerobic Digestion of Wastewater and Post-Treatment Processing of Sewage Sludge. Environ. Sci. Technol. 2012, 46, 90899096.

(19) Mamindy-Pajany, Y.; Sayen, S.; Mosselmans, J. F. W.; Guillon, E. Copper, Nickel and Zinc Speciation in a Biosolid-Amended Soil: $\mathrm{pH}$ Adsorption Edge, $\mu$-XRF and $\mu$-XANES Investigations. Environ. Sci. Technol. 2014, 48, 7237-7244.

(20) Kirpichtchikova, T. A.; Manceau, A.; Spadini, L.; Panfili, F.; Marcus, M. A.; Jacquet, T. Speciation and solubility of heavy metals in contaminated soil using X-ray microfluorescence, EXAFS spectroscopy, chemical extraction, and thermodynamic modeling. Geochim. Cosmochim. Acta 2006, 70, 2163-2190.

(21) Formentini, T. A.; Legros, S.; Fernandes, C. V. S.; Pinheiro, A.; Le Bars, M.; Levard, C.; Mallmann, F. J. K.; da Veiga, M.; Doelsch, E. Radical change of $\mathrm{Zn}$ speciation in pig slurry amended soil: Key role of nano-sized sulfide particles. Environ. Pollut. 2017, 222, 495-503. 
(22) Yamamoto, K.; Hashimoto, Y.; Kang, J.; Kobayashi, K. Speciation of Phosphorus Zinc and Copper in Soil and WaterDispersible Colloid Affected by a Long-Term Application of Swine Manure Compost. Environ. Sci. Technol. 2018, 52, 13270-13278.

(23) Inglezakis, V. J.; Zorpas, A. A.; Karagiannidis, A.; Samaras, P.; Voukkali, I.; Sklari, S. European Union Legislation On Sewage Sludge Management. Fresenius Environ. Bull. 2014, 23, 635-639.

(24) Romeo, A.; Vacchina, V.; Legros, S.; Doelsch, E. Zinc fate in animal husbandry systems. Metallomics 2014, 11, 1999-2009.

(25) Doelsch, E.; Basile-Doelsch, I.; Rose, J.; Masion, A.; Borschneck, D.; Hazemann, J. L.; Macary, H. S.; Bottero, J. Y. New Combination of EXAFS Spectroscopy and Density Fractionation for the Speciation of Chromium within an Andosol. Environ. Sci. Technol. 2006, 40, 7602-7608.

(26) Ravel, B.; Newville, M. ATHENA, ARTEMIS, HEPHAESTUS: data analysis for X-ray absorption spectroscopy using IFEFFIT. J. Synchrotron Radiat. 2005, 12, 537-541.

(27) Tella, M.; Bravin, M. N.; Thuriès, L.; Cazevieille, P.; ChevassusRosset, C.; Collin, B.; Chaurand, P.; Legros, S.; Doelsch, E. Increased zinc and copper availability in organic waste amended soil potentially involving distinct release mechanisms. Environ. Pollut. 2016, 212, 299-306.

(28) Hammer, D.; Keller, C.; McLaughlin, M. J.; Hamon, R. E. Fixation of metals in soil constituents and potential remobilization by hyperaccumulating and non-hyperaccumulating plants: Results from an isotopic dilution study. Environ. Pollut. 2006, 143, 407-415.

(29) Jacquat, O.; Voegelin, A.; Villard, A.; Marcus, M. A.; Kretzschmar, R. Formation of Zn-rich phyllosilicate, Zn-layered double hydroxide and hydrozincite in contaminated calcareous soils. Geochim. Cosmochim. Acta 2008, 72, 5037-5054.

(30) Jacquat, O.; Voegelin, A.; Kretzschmar, R. Local coordination of $\mathrm{Zn}$ in hydroxy-interlayered minerals and implications for $\mathrm{Zn}$ retention in soils. Geochim. Cosmochim. Acta 2009, 73, 348-363.

(31) Panfili, F.; Manceau, A.; Sarret, G.; Spadini, L.; Kirpichtchikova, T.; Bert, V.; Laboudigue, A.; Marcus, M. A.; Ahamdach, N.; Libert, M.-F. The effect of phytostabilization on $\mathrm{Zn}$ speciation in a dredged contaminated sediment using scanning electron microscopy, X-ray fluorescence, EXAFS spectroscopy, and principal components analysis. Geochim. Cosmochim. Acta 2005, 69, 2265-2284.

(32) Kelly, R. A.; Andrews, J. C.; DeWitt, J. G. An X-ray absorption spectroscopic investigation of the nature of the zinc complex accumulated in Datura innoxia plant tissue culture. Microchem. J. 2002, 71, 231-245.

(33) González, J. C.; Peariso, K.; Penner-Hahn, J. E.; Matthews, R. G. Cobalamin-Independent Methionine Synthase from Escherichia coli: A Zinc Metalloenzyme. Biochemistry 1996, 35, 12228-12234.

(34) Sarret, G.; Saumitou-Laprade, P.; Bert, V.; Proux, O.; Hazemann, J.-L.; Traverse, A.; Marcus, M. A.; Manceau, A. Forms of zinc accumulated in the hyperaccumulator Arabidopsis halleri. Plant Physiol. 2002, 130, 1815-1826.

(35) Doelsch, E.; Masion, A.; Moussard, G.; Chevassus-Rosset, C.; Wojciechowicz, O. Impact of pig slurry and green waste compost application on heavy metal exchangeable fractions in tropical soils. Geoderma 2010, 155, 390-400.

(36) Feder, F.; Bochu, V.; Findeling, A.; Doelsch, E. Repeated pig manure applications modify nitrate and chloride competition and fluxes in a Nitisol. Sci. Total Environ. 2015, 511, 238-248.

(37) McBride, M.; Sauve, S.; Hendershot, W. Solubility control of $\mathrm{Cu}, \mathrm{Zn}, \mathrm{Cd}$ and $\mathrm{Pb}$ in contaminated soils. Eur. J. Soil Sci. 1997, 48, 337-346.

(38) Karathanasis, A. D.; Johnson, D. M. C.; Matocha, C. J. Biosolid Colloid-Mediated Transport of Copper, Zinc, and Lead in WasteAmended Soils. J. Environ. Qual. 2005, 34, 1153-1164.

(39) Hernández, T.; Chocano, C.; Moreno, J.-L.; García, C. Use of compost as an alternative to conventional inorganic fertilizers in intensive lettuce (Lactuca sativa L.) crops-Effects on soil and plant. Soil Tillage Res. 2016, 160, 14-22.
(40) McGrath, S. P.; Chambers, B. J.; Taylor, M. J.; Carlton-Smith, C. H. Biofortification of zinc in wheat grain by the application of sewage sludge. Plant Soil 2012, 361, 97-108.

(41) Black, R. E. Zinc Deficiency, Infectious Disease and Mortality in the Developing World. J. Nutr. 2003, 133, 1485S-1489S.

(42) Wedepohl, K. H. Zinc. In Handbook of Geochemistry; SpringerVerlag: Berlin, 1978; Vol. II/3.

(43) Yamamoto, K.; Hashimoto, Y. Chemical Species of Phosphorus and Zinc in Water-Dispersible Colloids from Swine Manure Compost. J. Environ. Qual. 2017, 46, 461-465. 